\title{
AUSTRALIA'S CULTURAL INSTITUTIONS AND THE EFFICIENCY DIVIDEND: NOT A PRETTY PICTURE
}

\author{
Dr Kristin van Barneveld ${ }^{1}$
}

The Commonwealth government has a significant responsibility in collecting, maintaining and exhibiting Australian and international art and cultural artefacts to both educate and inform the public and preserve our political, social and cultural history.

There are a number of cultural agencies within the Commonwealth Government. These include the Australian Institute of Aboriginal and Torres Strait Islander Studies (AIATSIS), the National Archives of Australia (NAA), the National Gallery of Australia (NGA), the National Library of Australia

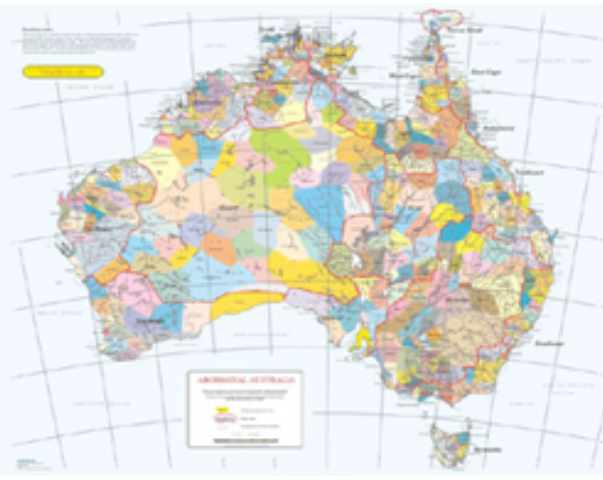

Figure 1

http://www.aiatsis.gov.au/aboriginal_studies_press/ab original_wall_map

1 Director, Policy and Research, Community and Public Sector Union and Honorary Research Associate, Workplace Research Centre, University of Sydney, kristin.vanbarneveld@cpsu.org.au.

Public Space: The Journal of Law and Social Justice (2009) Vol 3, Art 5, pp 1-28 
(NLA) and the Australian War Memorial (AWM). This paper briefly reviews the effect of Commonwealth funding practices on the operation of these agencies and concludes that the policies and practices of the last two decades have significantly damaged Australia's cultural agencies - something which the Rudd government must remedy in order to secure Australia's heritage and renew our focus on the arts.

Commonwealth cultural agencies are created by legislation which clearly articulates

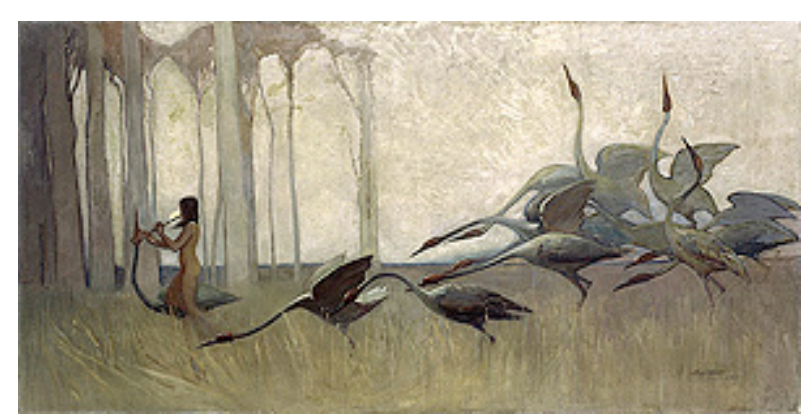

Figure 2 Sydney Long, The Spirit of the Planes (1914) their role. The National Gallery of Australia was established by the National Gallery Act (Cth) 1975. The functions of the Gallery are prescribed in the National Gallery Act (Cth) 1975. They include developing and maintaining a national art collection and exhibiting works from the collection. ${ }^{2}$ The collection is significant - the NGA holds assets including the national collection of artworks valued at $\$ 3.2$ billion. 'The national collection is the largest art collection in Australia- 150,000 works, valued at $\$ 3.3$ billion'. ${ }^{3}$

\footnotetext{
${ }^{2}$ National Gallery of Australia (2008) Annual Report 2007-08, Canberra, p 13.

${ }^{3}$ R Radford (2008), 'Joint Committee of Public Accounts and Audit: inquiry into the effects of the ongoing dividend on smaller public sector agencies’, Hansard, Thursday, 21 August, Canberra, p 4.
} 
The National Library Act 1960 outlines the functions of the National Library of Australia. Among other things, the Library is to develop and maintain a national collection of library material and to make this material available. In the Library's 2007-08 Annual Report, the Director General acknowledged that 'much of our strength comes from consistency, continuity and the pursuit of long-term objectives. Collecting, preserving and providing easy access to a diverse range of Australian resources is at the heart of what we do'.

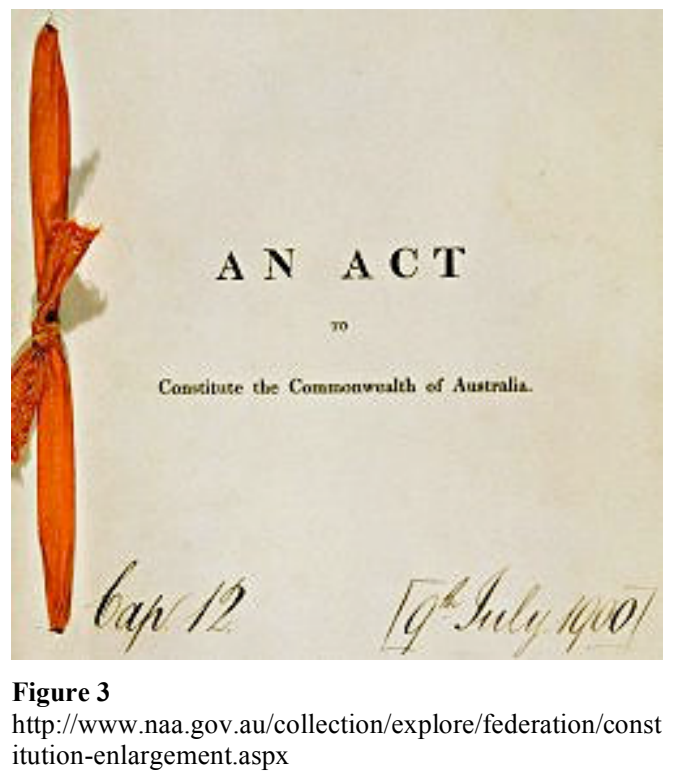

The National Archives of Australia 'was established under the Archives Act 1983. ... In 2001, the Archives became an executive agency under section 65 of the Public Service Act 1999, 5 The purpose of the Archives as defined under the Archives Act includes the management of Commonwealth Records, making records more than 30 years old publicly available, encouraging and facilitating the use of archival resources of the government and coordinating the preservation and use of Australian archival resources. Importantly, the Archives 'also contributes to the maintenance and understanding of political, social and cultural

\footnotetext{
${ }^{4}$ National Library of Australia, (2008) Annual Report 2007-08, Canberra, p 9.

${ }^{5}$ National Archives of Australia and National Archives of Australia Advisory Council, (2008) Annual Reports 2007-08, Canberra, p 9.
} 
values in Australia by' providing the archival resources to support effective and accountable government administration, and preserving and providing access to documentation of government. $^{6}$

To meet their clear legislative mandates, these agencies rely on the Commonwealth to provide adequate funding. This funding is to ensure that collections are accessible to all Australians without charge; that collections are not only maintained and enhanced but grow; and that travelling exhibitions allow access to as many Australians as possible.

However, for two decades the budgets of these agencies have been affected by the imposition of an annual arbitrary budget cut - the efficiency dividend. This, combined with the lack of focus by the Howard Government on the arts, had a significant impact both on the budgets and activities of cultural agencies and their ability to pay competitive wages in order to attract and retain staff. The efficiency dividend and its effects are detailed below before the remuneration practices of cultural agencies is discussed.

\section{The efficiency dividend}

\footnotetext{
${ }^{6}$ National Archives of Australia and National Archives of Australia Advisory Council (2008) ibid p10.
} 
The efficiency dividend was implemented by the Hawke Labor Government in 1986-

7. The dividend was a short term budget cut designed to require agencies to look for efficiencies within their operations. However as Table 1 shows, rather than being a short term budget cut, the Dividend has been applied to successive budgets and has increased over time. ${ }^{7}$

Table 1: The Efficiency Dividend

\begin{tabular}{|l|l|}
\hline Year & Percentage Efficiency Dividend \\
\hline $1986-7$ & $0.5 \%$ \\
\hline $1987-8$ to $1993-4$ & $1.25 \%$ \\
\hline $1994-5$ to $2004-5$ & $1.0 \%$ \\
\hline $2005-6$ to $2006-7$ & $1.25 \%$ \\
\hline $2007-8$ & 1.25 plus pro-rata of $2.0 \%$ \\
\hline $2008-9$ & $1.25 \%$ plus $2.0 \%$ of the same base \\
\hline $2009-10$ to $2010-11$ & $1.25 \%$ \\
\hline
\end{tabular}

While for the last few years the Dividend has meant an annual 1.25 per cent taken off agency budget allocations, in 2007, during the pre-election campaign, Kevin Rudd promised that if Labor won office, it would cut an additional 2 per cent from agency budgets to ensure efficiencies.

\footnotetext{
${ }^{7}$ Department of Finance and Deregulation (2008) Finance Submission to the Joint Committee of Public Accounts and Audit Inquiry into the Effects of the Ongoing Efficiency Dividend on Smaller Public Sector Agencies, Submission 25, http://www.aph.gov.au/house/committee/jpaa/efficdiv/subs/sub25.pdf, at 15 December 2008, p 2.
}

Public Space: The Journal of Law and Social Justice (2009) Vol 3, Art 5, pp 1-28 
However after more than two decades of arbitrary budget cuts, many agencies, particularly smaller agencies, have long run out of 'efficiencies'. The Acting Director General of the National Library recently suggested that it was ten years ago that the Library 'had got to the point where (the efficiency dividend) was no longer about efficiencies but cuts to service delivery and operations' ${ }^{8}$ Yet the efficiency dividend meant that the Library for 2008-9 had 'a reduction of $\$ 1.856 \mathrm{~m}$ in government appropriation funding'. ${ }^{9}$ Similarly, the budget of the National Archives for 2008-9 was reduced by $\$ 1.510 \mathrm{~m}$ as a result of the efficiency dividend. ${ }^{10}$ For the National Gallery the decrease was $\$ 1.295 \mathrm{~m}^{11}$ and the War Memorial budget was decreased in $2008-9$ by $\$ 1.197 \mathrm{~m}^{12}$

Following significant lobbying by the Community and Public Sector Union (CPSU), in June 2008, the Joint Committee on Public Accounts and Audit resolved to review the effects of the ongoing efficiency dividend on smaller public sector agencies.

${ }^{8}$ W Cathro (2008) 'Joint Committee of Public Accounts and Audit: inquiry into the effects of the ongoing dividend on smaller public sector agencies', Hansard, Thursday, 21 August, Canberra, p 40.

${ }^{9}$ National Library of Australia (2008) Submission to the Joint Committee of Public Accounts and Audit: Inquiry into the effects of the ongoing dividend on smaller public sector agencies, Submission 41, Canberra, p 1.

${ }^{10}$ National Archives of Australia (2008) Submission to the Joint Committee of Public Accounts and Audit: Inquiry into the effects of the ongoing dividend on smaller public sector agencies, Submission 27, Canberra, p 2.

${ }^{11}$ National Gallery of Australia (2008) Submission to the Joint Committee of Public Accounts and Audit: Inquiry into the effects of the ongoing dividend on smaller public sector agencies, Submission 6, Canberra, p 1 .

${ }^{12}$ Australian War Memorial (2008) Submission to the Joint Committee of Public Accounts and Audit: Inquiry into the effects of the ongoing dividend on smaller public sector agencies, Submission 26, Canberra, p 1 .

Public Space: The Journal of Law and Social Justice (2009) Vol 3, Art 5, pp 1-28 
Drawing from the evidence provided by members, the CPSU submission stated that the efficiency dividend had outlived any usefulness it once may have had as a productivity measure, and had become an unsustainable imposition on agency budgets. $^{13}$

As suggested by the quote from the National Library above, the CPSU position was reflected by cultural agencies. During the public hearings for the Inquiry, cultural agencies reported being unable to sufficiently grow collections, an inability to maintain collections, an inability to properly digitise collections, an inability to undertake the desired level of travelling exhibitions, an inability to innovate, an increased reliance on fundraising and an inability to attract and retain adequate staff due to a lack of funds to pay competitive wage rates. These specific impacts of the Dividend on these agencies are briefly discussed below.

\section{Impact on growth and maintenance of collections}

The National Library and National Gallery both raised concerns about their inability to meet their legislative obligation to grow or develop collections. In its submission to the Inquiry, the National Gallery reported that the current funding model does not

${ }^{13}$ CPSU (2008) Submission to the Joint Committee of Public Accounts and Audit: Inquiry into the effects of the ongoing dividend on smaller public sector agencies, Community and Public Sector Union Submission 58, Canberra.

Public Space: The Journal of Law and Social Justice (2009) Vol 3, Art 5, pp 1-28 
provide for 'the increasing costs of developing, managing and maintaining the growing national visual arts collection'. ${ }^{14}$

Similarly, the National Library submission detailed how the application of the efficiency dividend was at conflict with its statutory obligations. The submission drew attention to the requirement of the Library to 'build a national collection of library material which is comprehensive with respect to Australia and the Australian people'. ${ }^{15}$ It noted that 'building a collection of library material ... is labour intensive.


Each year the Library acquires approximately 250,000 unique physical collection items. Every item requires staff effort, intellectual and physical, to acquire it, catalogue it, and incorporate it into the collection'. ${ }^{16}$ In addition, many

Figure 4 Henry Moore's sculpture outside the National Library of Australia, Canberra, 18 June 1995

${ }^{14}$ National Gallery of Australia (2008) Submission to the Joint Committee of Public Accounts and Audit: Inquiry into the effects of the ongoing dividend on smaller public sector agencies, Submission 6, Canberra, p 4.

${ }^{15}$ National Library of Australia (2008) Submission to the Joint Committee of Public Accounts and Audit: Inquiry into the effects of the ongoing dividend on smaller public sector agencies, Submission 41, Canberra, $\mathrm{p} 2$.

${ }^{16}$ Ibid p 5.

Public Space: The Journal of Law and Social Justice (2009) Vol 3, Art 5, pp 1-28 
cost consequences flow from building a collection - including 'additional cost in collection management, storage and housing preservation of the collections' ${ }^{17}$

However the Library lamented that the 'required levels of collecting and service cannot be maintained into the future with funding that is continuously eroded in real terms'. ${ }^{18}$ The Acting Director General concluded that 'what we really need, ideally, is a funding formula that takes account of the growth that our statutes require us to make; instead, we have a funding formula that does the opposite'. ${ }^{19}$

\section{Impact on digitisation of collections}

Given the high use of internet based research in Australia and the increasing importance of preserving information digitally, it is not surprising that many agencies have dedicated resources to converting paper based records. However for key cultural agencies, these programs are under threat as the efficiency dividend has forced them to either delay or reduce the level of digitisation work they undertake.

\footnotetext{
${ }^{17}$ W Cathro (2008) 'Joint Committee of Public Accounts and Audit: inquiry into the effects of the ongoing dividend on smaller public sector agencies', Hansard, Thursday, 21 August, Canberra, p.5.

18 National Library of Australia (2008) Submission to the Joint Committee of Public Accounts and Audit: Inquiry into the effects of the ongoing dividend on smaller public sector agencies, Submission 41, Canberra, p 2.

${ }^{19}$ W Cathro (2008) 'Joint Committee of Public Accounts and Audit: inquiry into the effects of the ongoing dividend on smaller public sector agencies', Hansard, Thursday, 21 August, Canberra, p 5.
} 
For example, the Acting Director General of the National Library noted that 'over the past 15 years, Australia's knowledge has increasingly been created and distributed in digital form. Retaining a record of the knowledge of the nation in all forms is clearly a responsibility of the Library. With constantly declining resources, the Library's capabilities to capture, preserve and make digital knowledge available into the future are severely compromised'. The inability of the Library to adequately collect digital information is of considerable concern - first because, without redress, there will be 'significant loss of knowledge, history and culture' and second, 'the relevance of the Library to information seekers will gradually diminish as (it) fails to meet (its) statutory obligations to collect' ${ }^{20}$ Despite this fear, the Acting Director General of the Library noted before the Inquiry that one way the Library had absorbed the impact of the efficiency dividend was to cease the digitisation of manuscript collections. ${ }^{21}$

Similarly, the Principal of Australian Institute for Aboriginal and Torres Strait Islander Studies (AIATSIS) explained the high importance placed on digitising sections of their collection. During the public hearings for the Inquiry he explained that AIATSIS is 'currently racing against time to digitise the most vulnerable parts of our collections before analogue technologies become completely obsolete. If we fail,

\footnotetext{
${ }^{20}$ National Library of Australia (2008) Submission to the Joint Committee of Public Accounts and Audit: Inquiry into the effects of the ongoing dividend on smaller public sector agencies, Submission 41, Canberra, p 6.

${ }^{21}$ W Cathro (2008) 'Joint Committee of Public Accounts and Audit: inquiry into the effects of the ongoing dividend on smaller public sector agencies', Hansard, Thursday, 21 August, Canberra, pp 2930 .
} 
these items will be lost forever'. However AIATSIS was required to undertake this increased work to protect the heritage of Aboriginal and Torres Strait Islander peoples despite having reduced 'staffing in this program by eight positions to comply with the requirements of the dividend'.22

The pressure to digitise collections and properly record them was also felt by the National Archives which noted that the volume of paper archival material which must be collected and stored digitally is not decreasing. The Archives described this as a 'digital collecting challenge' and something which it will not be able to meet without an injection of new funding. ${ }^{23}$

The postponing of digitisation by some agencies as a direct result of the efficiency dividend means that access to these records will be delayed until sufficient funds are available to continue this important work. There is a significant risk that due to the efficiency dividend, some of Australia's heritage will be lost forever.

\section{Impact on travelling exhibitions}

${ }^{22}$ S Larkin (2008) 'Joint Committee of Public Accounts and Audit: inquiry into the effects of the ongoing dividend on smaller public sector agencies', Hansard, Thursday, 21 August, Canberra, p 3.

${ }^{23}$ National Archives of Australia (2008) Submission to the Joint Committee of Public Accounts and Audit: Inquiry into the effects of the ongoing dividend on smaller public sector agencies, Submission 27, Canberra, p 3. 
To educate and inform the public, cultural agencies have a legislative obligation to exhibit works from their collections. These exhibits travel not only to capital cities but also provide access to those in regional centres. However cutting travelling exhibitions is one way agencies including the National Archives, National Library and AIATSIS have sought to absorb the budget cuts imposed by the efficiency dividend.

The National Archives of Australia submitted to the Inquiry that it had reduced its travelling exhibitions and future exhibitions would be undertaken only when the Archives could secure third-party sponsorship to fund the venture. The impact of this change was to '... significantly decrease the reach of public access to the records of the Commonwealth, to people outside capital cities'. ${ }^{24}$

${ }^{24}$ Ibid.

Public Space: The Journal of Law and Social Justice (2009) Vol 3, Art 5, pp 1-28 


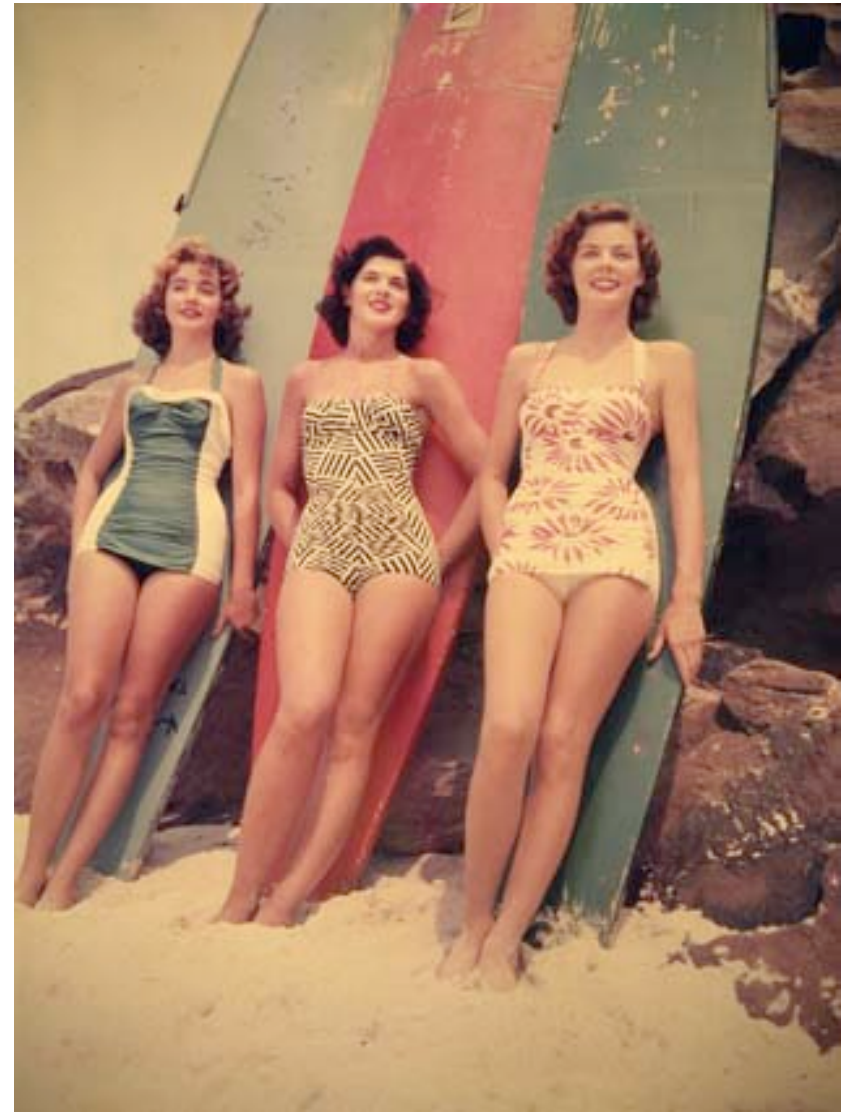

Figure 5 Beaches - 1952 Miss Pacific finalists Mary Clifton Smith, Pamela Jansen and Judy Worrad, stand in front of surf boards on Bondi Beach, Sydney

http://naa12.naa.gov.au/scripts/PhotoSearchItemDetail.asp?B=11697818
At the Inquiry, the Director

General of National Archives noted that "until we received the funding last week for our Max Dupain exhibition, it was over three years since we had developed a new exhibition. So, while we have had five shows on the road, two things are happening: firstly, they are looking very tired, and, secondly, they are coming off. As they come off, we will go from being a major touring exhibition program equal to the other institutions, or similar, to being a very bit player with perhaps just one exhibition on the road, and it will become apparent to users what the impact has been'. ${ }^{25}$

The impact of the efficiency dividend on the travelling exhibitions of the National Gallery has also been significant. The Gallery has reduced the number of travelling

${ }^{25}$ C Gibbs (2008) 'Joint Committee of Public Accounts and Audit: inquiry into the effects of the ongoing dividend on smaller public sector agencies', Hansard, Thursday, 21 August, Canberra, p 30. 
exhibitions from fourteen in $2007-8$ to nine in $2008-9 .{ }^{26}$ In past years the Gallery has released 'around four new exhibitions each year. For 2008-9 there will be one'. ${ }^{27}$

Similarly, the National Library 'can no longer afford to do large travelling exhibitions, ${ }^{28}$ has placed a "moratorium on loans for exhibitions for all borrowers except other Commonwealth institutions and state libraries ${ }^{29}$ and has reduced the outreach programs it undertakes. ${ }^{30}$

These cuts to travelling exhibitions are significant and have a very clear impact on the ability of all Australians and particularly those in non-metropolitan areas, to access the collections held by our cultural institutions.

\section{Impact on innovation and the use of new technology}

Digitisation and other investment in new technology requires significant funding and both the National Library and Archives noted that the efficiency dividend had resulted

\footnotetext{
${ }^{26}$ R Radford (2008), 'Joint Committee of Public Accounts and Audit: inquiry into the effects of the ongoing dividend on smaller public sector agencies', Hansard, Thursday, 21 August, Canberra, p 29.

27 National Gallery of Australia (2008) Submission to the Joint Committee of Public Accounts and Audit: Inquiry into the effects of the ongoing dividend on smaller public sector agencies, Submission 6, Canberra, p 3.

${ }^{28}$ W Cathro (2008) 'Joint Committee of Public Accounts and Audit: inquiry into the effects of the ongoing dividend on smaller public sector agencies', Hansard, Thursday, 21 August, Canberra, p 2930 .

${ }^{29}$ National Library of Australia (2008) Submission to the Joint Committee of Public Accounts and Audit: Inquiry into the effects of the ongoing dividend on smaller public sector agencies, Submission 41, Canberra, p 4.

${ }^{30}$ Ibid.
}

Public Space: The Journal of Law and Social Justice (2009) Vol 3, Art 5, pp 1-28 
in a reduction in investment in new technology and innovation. ${ }^{31}$ The National Library for example had employed someone full time to lead and direct major innovative activities. This position had become effectively part time as a result of a lack of available funds. ${ }^{32}$

Although the National Archives reported that it 'endeavours to identify opportunities for innovation or business process re-engineering' it was noted that 'at some future point this will no longer be possible without an injection of new funding, 33

Without innovation, the role that Australia can play in preserving Australia's cultural heritage and making it available as widely as possible is diminished. This will surely place Australia in a weaker position internationally.

\section{Increased reliance on fundraising}

It is a sad indictment that some agencies reported an increasing reliance on private sector sponsorship to counteract the budget cuts of the efficiency dividend. The

\footnotetext{
${ }^{31}$ Ibid.

${ }^{32}$ W Cathro (2008) 'Joint Committee of Public Accounts and Audit: inquiry into the effects of the ongoing dividend on smaller public sector agencies', Hansard, Thursday, 21 August, Canberra, p.2930 .

${ }^{33}$ National Archives of Australia (2008) Submission to the Joint Committee of Public Accounts and Audit: Inquiry into the effects of the ongoing dividend on smaller public sector agencies, Submission 27, Canberra, p 3.
} 
Director of the National Gallery reported to the Inquiry that the Gallery 'could 1 efficiency dividends over the couple of decades without our very extensive fundrais year' ${ }^{34}$ However in its submission the Gallery also raised concerns that fundraising ac affected by the efficiency dividend because the reduction in programs and operating ac undertake with ever reduced government funding will 'impact negatively on the reputa and therefore its ability to attract sponsorship'.35

The War Memorial also relies heavily on fundraising having budgeted for $\$ 7$ million from non-government sources over the 2008-9 financial year. According to its Director, the money 'is quite important because it enables us to do much more on our core functions of ceremonies, interpretation, events and things like that which are essential for a very active museum and cultural institution. Without that money, we would be very lessened in what we can achieve and contribute as an institution. ${ }^{36}$ However the Memorial has also raised concerns about its ability to attract future sponsorship from the private sector. While non-government funding is a key source of

${ }^{34}$ R Radford (2008), 'Joint Committee of Public Accounts and Audit: inquiry into the effects of the ongoing dividend on smaller public sector agencies', Hansard, Thursday, 21 August, Canberra, p 20.

${ }^{35}$ National Gallery of Australia (2008) Submission to the Joint Committee of Public Accounts and Audit: Inquiry into the effects of the ongoing dividend on smaller public sector agencies, Submission 6, Canberra, p 4.

${ }^{36}$ S Gower (2008) 'Joint Committee of Public Accounts and Audit: inquiry into the effects of the ongoing dividend on smaller public sector agencies’, Hansard, Thursday, 21 August, Canberra, p 3. 
revenue 'and all endeavours to increase this source are pursued', the Memorial is concerned that given the global financial crisis raising these funds will be difficult. ${ }^{37}$

From the evidence presented above, it is clear that the reliance of cultural agencies on the private sector to raise sufficient funds to hold exhibitions and maintain their level of service to the public is significant. However the global financial crisis may well impact on the level of funds agencies can raise. Either agencies will need to review the level at which they can serve the Australian public or the government will need to step in and properly fund cultural agencies to undertake their role as mandated by legislation.

\section{Other impacts}

Before turning to the staffing and salary impacts of the efficiency dividend there are several other consequences of the efficiency dividend reported by agencies that should be considered.

First is the level at which agencies are able to collaborate. The Director General of the National Archives noted that while Archives 'used to run very good collaborative programs with the State Library and with the State archives and go out to distant sites'

\footnotetext{
${ }^{37}$ Australian War Memorial (2008) Submission to the Joint Committee of Public Accounts and Audit: Inquiry into the effects of the ongoing dividend on smaller public sector agencies, Submission 26, Canberra, $\mathrm{p} 2$.
} 
this collaborative work was done 'in a very minimal way now'. ${ }^{38}$ The National Library also reported that there had been a 'reduction in the Library's national and international leadership and collaborative activities, including a reduction in the assistance which the Library provides to other libraries in the Asia/Pacific region'. 39

Second is the impact on publications. In its submission before the Inquiry, the National Gallery of Australia reported that it was Australia's biggest art publishing house. The Director noted that this was 'a major thing to aspire to'. However because of the efficiency dividend, the Gallery had to 'cut out four publications this coming financial year that we had planned' and explained that 'they are not going to be stopped altogether; we will just do them in other years, one or two at a time. We find it very disappointing that we have to do that'. ${ }^{40}$

Third is the impact on collections as a result of staffing cuts. The National Library reported that because one of its staff will be withdrawn from Jakarta from 2009, there will be 'an inevitable decline in the quality of the Library's world-class Indonesian collection'. This affects not only the Indonesian collection of the National Library but

${ }^{38}$ C Gibbs (2008) 'Joint Committee of Public Accounts and Audit: inquiry into the effects of the ongoing dividend on smaller public sector agencies', Hansard, Thursday, 21 August, Canberra, p 30.

${ }^{39}$ W Cathro (2008) 'Joint Committee of Public Accounts and Audit: inquiry into the effects of the ongoing dividend on smaller public sector agencies', Hansard, Thursday, 21 August, Canberra, p 2930 .

${ }^{40}$ R Radford (2008), 'Joint Committee of Public Accounts and Audit: inquiry into the effects of the ongoing dividend on smaller public sector agencies', Hansard, Thursday, 21 August, Canberra, p 29. 
the quality and level of collection from the wider region for the National Library and the six other Australian libraries that the Jakarta officer collected for. ${ }^{41}$

It is clear that the budget cuts as a result of the efficiency dividend are having far reaching effects on the work undertaken by Australia's cultural agencies. Removing an officer from Jakarta is just one of the staffing implications of the efficiency dividend. More staffing effects are detailed below.

\section{Staffing}

The Library, Gallery, Archives and War Memorial all reported that staff numbers have been and/or will be reduced as a result of the efficiency dividend - at a time when most agencies reported that their workload is increasing.

Not only does the reduction in staff numbers increase the workload of those remaining but it also necessitates a cut in services that these agencies can provide. For example, at the National Library, there has been a 'reduction in the number of staff providing services in reading rooms, and in the number of staff undertaking collection processing'. The Library's submission noted that although 'these reductions have been carefully targeted to minimise the impact on readers, there will be inevitable

\footnotetext{
${ }^{41}$ National Library of Australia (2008) Submission to the Joint Committee of Public Accounts and Audit: Inquiry into the effects of the ongoing dividend on smaller public sector agencies, Submission 41, Canberra, p 4.
} 
reductions in the level of access to the Library's collections'. ${ }^{42}$ The submission goes further to note that 'the Library's forward projections indicate that, if the 1.25 per cent efficiency dividend continues for another three years, the number of staff in 2011-12 will decrease by a further 10 per cent, meaning a reduction of 45 staff compared to this year. The Library will not be a viable institution with staff numbers at that level' 43

The National Gallery also reported reducing staffing levels over time to meet the efficiency dividend. The average staffing level for the Gallery was 250 full time equivalent staff in 2007-8. This has reduced to 242 over $2008-9 .{ }^{44}$

Similarly, in its submission, the National Archives stated that one way to meet the efficiency dividend and be able to fund the increasing demands of digitisation is to reduce staffing levels through 'not filling vacant positions and natural attrition' ${ }^{45}$ Yet it noted that this approach is not sustainable given the increasing demand on the services of the Archives.

${ }^{42}$ Ibid.

${ }^{43}$ Ibid, p 5.

${ }^{44}$ National Gallery of Australia (2008) Submission to the Joint Committee of Public Accounts and Audit: Inquiry into the effects of the ongoing dividend on smaller public sector agencies, Submission 6, Canberra, $\mathrm{p} 4$.

${ }^{45}$ National Archives of Australia (2008) Submission to the Joint Committee of Public Accounts and Audit: Inquiry into the effects of the ongoing dividend on smaller public sector agencies, Submission 27, Canberra, p 4. 
Finally, the Australian War Memorial noted in its submission that 'the Memorial will probably have no option but to reduce staffing levels and other activities from 200910 onwards'. However the Memorial expressed a hope that fundraising from the private sector could be used to offset the level of staff attrition required. The Memorial submission stated that 'it is hoped that any staff reductions are achieved via natural attrition as the Memorial does not have any cash reserves available to support redundancies'. 46

At a time when agencies are rushing to digitise fragile collections and continue to work under a mandate on agencies to grow collections, these staff cuts are untenable. Australia's cultural agencies should not have to rely on the private sector to prop up their staffing levels, nor on the unskilled labour of volunteers so that they can provide an appropriate level of collection maintenance, growth and service to the community.

\section{Impact on rates of pay}

Although agencies have had to reduce staffing numbers to meet the efficiency dividend, they also need to attract and retain skilled staff to undertake specialist work. The National Gallery in its submission to the Inquiry noted that it competes in the labour market for the services of 'highly skilled professional staff' and these staff are

\footnotetext{
${ }^{46}$ Australian War Memorial (2008) Submission to the Joint Committee of Public Accounts and Audit: Inquiry into the effects of the ongoing dividend on smaller public sector agencies, Submission 26, Canberra, p 2 .
}

Public Space: The Journal of Law and Social Justice (2009) Vol 3, Art 5, pp 1-28 
'vital to the achievement of the highest standards of international museum practice'. Yet the Gallery is unable to offer salaries that are comparable to large agencies and consequently finds it difficult to compete. For example, the employee expenses of the Gallery in 2008-9 'will increase by around 4 per cent while government funding for employee expenses will reduce by around 1.5 per cent' ${ }^{47}$

Similarly the National Library reported that it's ability to 'fund a sufficient number of skilled staff is particularly severe. The Library's cost per employee will increase by $4 \%$ in 2008-09. By contrast, the funds available to the Library for employee expenses will be effectively reduced in net terms by $2.5 \%$. The Library needs to compete in the labour market for the services of skilled staff. Smaller agencies like the Library are not consistently able to offer salaries at the levels available from larger government agencies'. $^{48}$

These two examples confirm that while larger agencies with new initiatives have found ways to maintain or increase real wages, those with smaller budgets and/or less dynamic program responsibilities, like cultural agencies, have not. ${ }^{49}$

\footnotetext{
${ }^{47}$ National Gallery of Australia (2008) Submission to the Joint Committee of Public Accounts and Audit: Inquiry into the effects of the ongoing dividend on smaller public sector agencies, Submission 6, Canberra, p 1 .

${ }^{48}$ National Library of Australia (2008) Submission to the Joint Committee of Public Accounts and Audit: Inquiry into the effects of the ongoing dividend on smaller public sector agencies, Submission 41, Canberra, p 2.

${ }^{49}$ CPSU (2008) Submission to the Joint Committee of Public Accounts and Audit: Inquiry into the effects of the ongoing dividend on smaller public sector agencies, Community and Public Sector Union Submission 58, Canberra,
} 
This is clear from Chart 1 which shows that when more than 80 collective agreements from across the Australian Public Service are compared, cultural agencies generally pay below the average. In fact, the difference is several thousand dollars and the disparity increases as you move further up the APS classification scale to the more skilled positions (from APS 1 to APS 6 which is the highest, non-managerial role).

Chart 1: APS 3 and APS 6 Collective Agreement Rates of Pay, December 2008

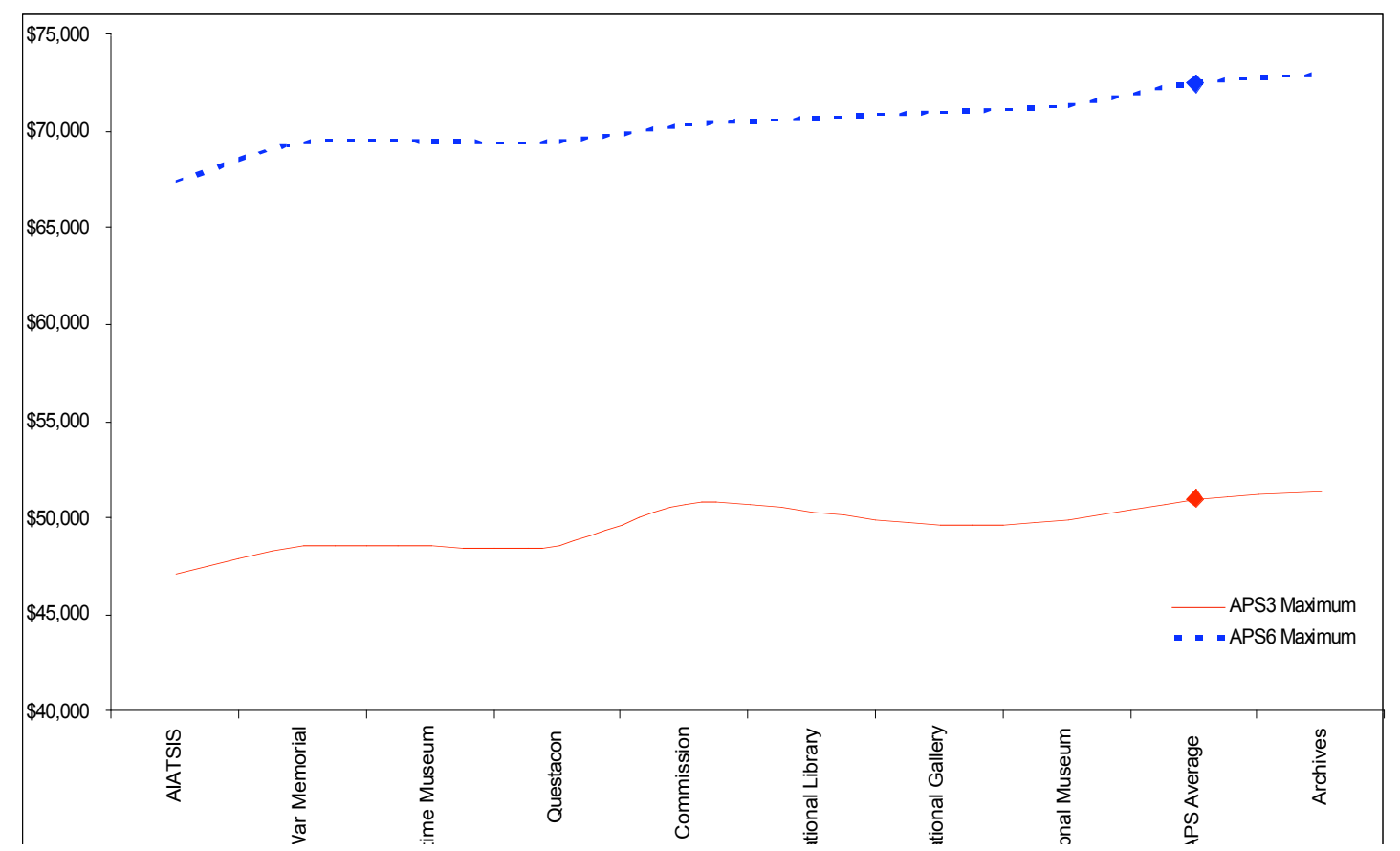

Source: CPSU Wages Database, December 2008

As a result of falling behind in salaries, smaller APS agencies are clearly less able to compete for staff with higher paying public sector agencies and with the private 
sector. The Acting Director General of the National Library summed it up simply before the Inquiry when he said that 'we are probably less able than other agencies to compete for the skills that we need. ... We attempt to be active and relevant in an online world and, in that area and other areas, we need skills, including strong information management skills. It is quite challenging to compete for those skills in the marketplace'. ${ }^{5}$

\section{Concluding comment}

The cost of the efficiency dividend to our cultural heritage is clear. Agencies are cutting exhibitions, struggling to meet their mandate to grow collections, and reducing the amount of innovative work they undertake, including the digitisation of collections. In an environment where they need to attract and retain staff to undertake this complex work, they are unable to compete on wages.

On 4 December 2008, the Report into the Inquiry into the Effect of the Efficiency Dividend on Small Agencies was tabled. The Report recognised the impact of the efficiency dividend on these agencies, and paid particular attention to cultural agencies. The Committee found that it was inappropriate for cultural agencies with significant assets be subject to the same financial restraints as applied to other

\footnotetext{
${ }^{50} \mathrm{~W}$ Cathro (2008) 'Joint Committee of Public Accounts and Audit: inquiry into the effects of the ongoing dividend on smaller public sector agencies', Hansard, Thursday, 21 August, Canberra, p 6.
} 
agencies. The Report recommended that the 'Department of Finance and Deregulation, the Australian Public Service Commissioner and each cultural agency develop a new funding model for cultural agencies'. The Committee stressed that it is important that cultural agencies be able to meet their legislated mandate to grow and develop their collections and that they should be funded to do so. However the Rudd Government has yet to provide its response to the Report. How it responds will give a clear indication of the importance this Government places on Australia's cultural heritage. 


\section{Bibliography}

Australian War Memorial (2008) Submission to the Joint Committee of Public Accounts and Audit: Inquiry into the effects of the ongoing dividend on smaller public sector agencies, Submission 26, Canberra.

Cathro W (2008) 'Joint Committee of Public Accounts and Audit: inquiry into the

effects of the ongoing dividend on smaller public sector agencies', Hansard, Thursday, 21 August, Canberra.

CPSU (2008) Submission to the Joint Committee of Public Accounts and Audit: Inquiry into the effects of the ongoing dividend on smaller public sector agencies, Community and Public Sector Union Submission 58, Canberra.

Department of Finance and Deregulation (2008) Finance Submission to the Joint Committee of Public Accounts and Audit Inquiry into the Effects of the Ongoing Efficiency Dividend on Smaller Public Sector Agencies, Submission 25, http://www.aph.gov.au/house/committee/jpaa/efficdiv/subs/sub25.pdf, at 15 December. 
Gibbs C (2008) 'Joint Committee of Public Accounts and Audit: inquiry into the effects of the ongoing dividend on smaller public sector agencies', Hansard, Thursday, 21 August, Canberra.

Gower S (2008) 'Joint Committee of Public Accounts and Audit: inquiry into the effects of the ongoing dividend on smaller public sector agencies', Hansard, Thursday, 21 August, Canberra.

Larkin S (2008) 'Joint Committee of Public Accounts and Audit: inquiry into the effects of the ongoing dividend on smaller public sector agencies', Hansard, Thursday, 21 August, Canberra.

Linehan G (2008) 'Joint Committee of Public Accounts and Audit: inquiry into the effects of the ongoing dividend on smaller public sector agencies', Hansard, Thursday, 21 August, Canberra.

National Archives of Australia (2008) Submission to the Joint Committee of Public Accounts and Audit: Inquiry into the effects of the ongoing dividend on smaller public sector agencies, Submission 27, Canberra.

National Archives of Australia and National Archives of Australia Advisory Council (2008) Annual Reports 2007-08, Canberra. 
National Gallery of Australia (2008) Annual Report 2007-08, Canberra.

National Gallery of Australia (2008) Submission to the Joint Committee of Public Accounts and Audit: Inquiry into the effects of the ongoing dividend on smaller public sector agencies, Submission 6, Canberra.

National Library of Australia (2008) Annual Report 2007-08, Canberra.

National Library of Australia (2008) Submission to the Joint Committee of Public Accounts and Audit: Inquiry into the effects of the ongoing dividend on smaller public sector agencies, Submission 41, Canberra.

Radford R (2008) 'Joint Committee of Public Accounts and Audit: inquiry into the effects of the ongoing dividend on smaller public sector agencies', Hansard, Thursday, 21 August, Canberra.

Public Space: The Journal of Law and Social Justice (2009) Vol 3, Art 5, pp 1-28 